\title{
Trends in energy and nutrient supply in Trinidad and Tobago from 1961 to 2007 using FAO food balance sheets
}

\author{
Tony Sheehy ${ }^{1, *}$ and Sangita Sharma ${ }^{2}$ \\ ${ }^{1}$ School of Food and Nutritional Sciences, University College Cork, Cork, Republic of Ireland: ${ }^{2}$ Li Ka Shing \\ Centre for Health Research Innovation, Department of Medicine, University of Alberta, Edmonton, Canada
}

Submitted 19 January 2012: Final revision received 6 November 2012: Accepted 12 November 2012: First published online 4 January 2013

\begin{abstract}
Objective: Trinidad and Tobago has experienced an epidemiological transition over recent decades characterised by reduced rates of communicable diseases but rapidly increasing rates of obesity and non-communicable chronic diseases. The objective of the present study was to investigate the changes in energy and nutrient supply that have taken place in Trinidad and Tobago between 1961 and 2007.

Design: Food balance sheets for each year between 1961 and 2007 were downloaded from the FAOSTAT database and daily per capita supply for seventeen food commodity groupings was calculated. After appropriate coding, energy and nutrient supply were determined using dietary analysis software. Setting: FAO food balance sheets for Trinidad and Tobago from 1961 to 2007. Subjects: None.

Results: The food supply in 2007 provided an extra $1561 \mathrm{~kJ}$ (373 kcal)/capita per d than it did in 1961. Energy from carbohydrate as a percentage of total energy fell from $62 \%$ in 1961 to $57 \%$ in 2007 , whereas energy from fat as a percentage of total energy increased from $26 \%$ to over $30 \%$ and now lies at the upper end of WHO recommendations. Sugars increased from $20 \%$ to over $26 \%$ of total energy and are well above WHO recommendations. When expressed on a nutrient density basis, supplies of vitamin A, folate and Ca are lower than WHO recommendations.

Conclusions: Nutritional imbalances in the Trinidadian food supply need to be addressed to combat the rise in nutrition-related chronic disease that is projected to cause increased disability and premature death in the country in the coming years.
\end{abstract}

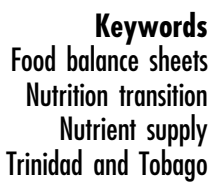

Trinidad and Tobago is a Caribbean nation (population $1 \cdot 3$ million) situated off the north-east coast of Venezuela. The country is dominated by two major cultural traditions: Creole and East Indian. Creole is a mixture of African elements with Spanish, French and British colonial influences, while the East Indian tradition originated with the arrival of indentured servants from India to work on the sugar plantations after the abolition of slavery in $1833^{(1)}$. Today, the country's multi-ethnic population consists of people of East Indian descent $40.3 \%$, African descent $39.5 \%$, mixed descent $18 \cdot 4 \%$, Europeans $0 \cdot 6 \%$, and Chinese and others $1 \cdot 2 \%{ }^{(2)}$. From 1960 to 2009 the average life expectancy of Trinidadians at birth rose from 63.5 to 69.6 years $^{(3)}$. During the same time period, however, the country has experienced an epidemiological transition characterised by a shift in leading causes of death from communicable to noncommunicable chronic diseases, including heart disease, cancers, cerebrovascular diseases, diabetes mellitus and hypertensive diseases ${ }^{(4-6)}$. In 2004 Trinidad and Tobago ranked 4th highest in the Americas for mortality from non-communicable diseases ${ }^{(7)}$. Estimated age-standardised mortality rates from CVD, diabetes mellitus and cancers in that year were 364, 128 and 123 per 100000 population, respectively, compared with 179, 17 and 133 per 100000 in the USA ${ }^{(7)}$. Diabetes has become a major public health burden ${ }^{(8)}$ with prevalence rates having increased from $1.3 \%$ in the 1950 s to more than $12 \%$ in the $1990 \mathrm{~s}^{(9)}$. Total direct and indirect costs attributed to diabetes in Latin America and the Caribbean were estimated at \$US 284.5 million in $2000^{(10)}$. This escalating economic burden due to noncommunicable chronic disease is set to continue with the increasing prevalence of metabolic syndrome components such as obesity, dyslipidaemia and insulin resistance ${ }^{(11)}$. The WHO Global InfoBase Obesity Comparison Tool ${ }^{(7)}$ predicted that by 2010 some $81 \%$ of women and $65 \%$ of men in Trinidad and Tobago would be overweight, and that of these, $53 \%$ of women and $19 \%$ of men would be obese. In terms of BMI, this would rank the country 10th highest in the world for females (mean BMI $=30 \cdot 6 \mathrm{~kg} / \mathrm{m}^{2}$ ) and $33 \mathrm{rd}$ for males (mean BMI $=26 \cdot 6 \mathrm{~kg} / \mathrm{m}^{2}$ ).

Several factors are thought to have contributed to the shift in mortality patterns from communicable to 
non-communicable chronic diseases in the Caribbean. These include greater access to high-fat/high-energy foods, decreased consumption of fruit and vegetables, decreased physical activity and the adoption of an increasingly sedentary lifestyle ${ }^{(6)}$. Diet and a healthy lifestyle are important components of non-communicable chronic disease prevention ${ }^{(12)}$ and assessment of dietary intake patterns can provide insights into nutrient intakes and dietary adequacy, upon which chronic disease associations can be drawn and public health strategies based. In Trinidad and Tobago, however, there have been few studies assessing dietary intake.

At their crudest level, dietary trends can be followed using aggregate data from food production, imports and exports $^{(13)}$. This is called the food disappearance method and utilises national food balance sheets compiled annually by the $\mathrm{FAO}^{(14)}$. Although these data represent the annual per capita supply of commodities available for consumption within a country rather than the actual dietary intakes of individuals, provided they are analysed appropriately they can reveal useful information on the overall changes in energy and nutrient supply taking place within a country over several decades. This approach is especially useful for dealing with lower- and middle-income countries undergoing nutrition transition, where few, if any, national food consumption studies may have ever been carried out. In a previous study we analysed FAO food balance sheets to investigate changes in per capita energy and macronutrient supply since the early 1960s in the neighbouring Caribbean island of Barbados ${ }^{(15)}$. Commodities were coded using dietary analysis software, using a list of commonly consumed foods from a population-specific quantitative FFQ $(\mathrm{QFFQ})^{(16)}$ to inform the coding process. A QFFQ with a list of commonly consumed foods for Trinidad and Tobago has since become available ${ }^{(17)}$. The objective of the present study was to analyse the FAO food balance sheets for Trinidad and Tobago with the aid of this instrument in order to characterise the changes in per capita energy, macronutrient and micronutrient supply that have taken place there between 1961 and 2007.

\section{Methods}

FAO food balance sheets for Trinidad and Tobago for the period 1961-2007 were downloaded as csv files from the FAOSTAT database ${ }^{(14)}$. These food balance sheets provide overall supply (as $\mathrm{kg} /$ capita per annum) for food commodities including cereals, starchy roots, vegetables, fruits, oilseeds and oilseed oils, treenuts, animal fats, milk, meats, eggs and fish. The full list of commodities is shown in the Appendix. Having imported the data into Microsoft ${ }^{\circledR}$ Office Excel 2003, supply was then converted to g/capita per $\mathrm{d}$.

In order to calculate the energy and nutrient supply, the foods were coded and entered into WISP version $3 \cdot 0$ dietary analysis software. The food composition database supplied with this software is from McCance and Widdowson's The Composition of Foods, 5th and 6th editions plus supplements ${ }^{(18)}$. For consistency and wherever possible, foods were coded as being in their most unprocessed form (e.g. 'bananas, weighed with skin', 'barley, whole grain, raw', etc.). However certain broad categories, such as peas, beans, treenuts, those referring to fish and those labelled as 'other', were lacking in detail about the specific foods that made up the category. To code these categories in a way that would more closely reflect the Trinidadian diet we referred to the food list of a QFFQ that was recently developed specifically for this population by one of the authors (S.S.) ${ }^{(17)}$. Using the 146 -item food list as a guide, we coded 'peas' as pigeon peas, 'beans' as green beans, and 'treenuts' as almonds and cashew nuts. We populated the category 'fish' with cod, tuna, herring and sardines. 'Pulses (other)' was populated with split peas, lentils and chick peas. 'Vegetables (other)' was populated with cabbage, carrots, taro leaves, pumpkin, beetroot, aubergine, okra, sweetcorn, spinach, cucumber, lettuce, peppers, watercress and avocado. The category 'citrus (other)' contained clementines, while 'fruits (other)' contained mangoes, papaya, pears, plums, melon and sapodilla. For categories where this procedure was carried out, supply was divided equally among the constituent foods. Overall, the commodities we coded accounted for over $98 \%$ of the total energy supply. We excluded certain minor categories such as tea, coffee, other sweeteners and spices either because of low energy contribution or lack of information.

The FAO food balance sheets are limited in the amount of nutritional information they provide. For example, they provide no information on carbohydrates (e.g. sugars, starch and fibre), fatty acids, cholesterol, amino acids or micronutrients. However they do provide estimates of per capita energy, protein and fat supply, and these values can be compared with the calculated values derived from the dietary analysis software in order to check whether appropriate coding of the commodities has been carried out. To determine the level of agreement between the food balance sheet estimates and our calculated values for energy, protein and fat supply, we obtained Pearson correlations using Microsoft ${ }^{\circledR}$ Office Excel 2003. Statistical significance of correlations was accepted at the $5 \%$ level. All tests were two-sided.

\section{Results}

\section{Food balance sheet estimates and calculated values for per capita energy, protein and fat supply}

Figure 1(a) shows the relationship between estimated daily per capita energy supply for Trinidad and Tobago according to the FAO food balance sheets and the values we derived using dietary analysis software. On average, 
(a)

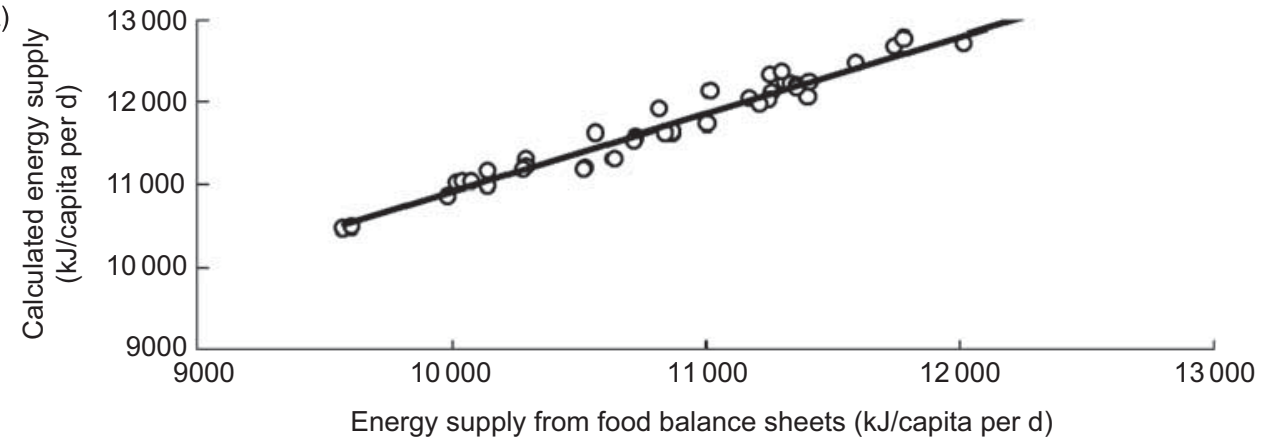

(b)

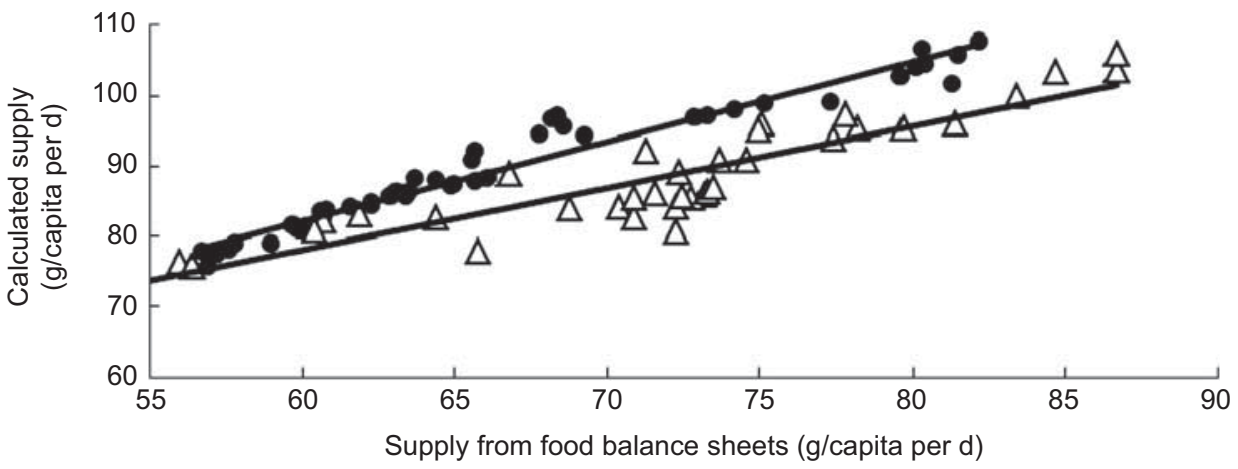

Fig. 1 Relationship between FAO food balance sheet estimates and our calculated values for (a) energy (O) and (b) protein ( $\bullet$ ) and fat $(\triangle)$ supply in Trinidad and Tobago. Regression equations: $y=0.9435 x+1484 \cdot 7, R^{2}=0.976$ for energy; $y=1 \cdot 1347 x+14 \cdot 078$, $R^{2}=0.952$ for protein; $y=0.8773 x+25 \cdot 423, R^{2}=0.910$ for fat

our values were some $7 \%$ higher than the food balance sheet estimates, but the relationship between them was highly significant $\left(R^{2}=0.976, P<0 \cdot 0001\right)$. For fat and protein supply, our values were, on average, some $25 \%$ and $35 \%$ higher, respectively, than the estimates provided on the food balance sheets. Again, however, there was a strong and statistically significant correlation between them $\left(R^{2}=0.910, P<0.0001\right.$ for fat and $R^{2}=0.952$, $P<0 \cdot 0001$ for protein; Fig. 1(b)).

\section{Energy and macronutrients}

Figure 2(a) shows that the trends in energy supply in Trinidad and Tobago between 1961 and 2007 according to the food balance sheet estimates and our calculated values were virtually identical. According to our calculations, energy supply increased by some $1561 \mathrm{~kJ}$ ( $373 \mathrm{kcal}$ )/capita per d between 1961 and 2007. There was a sharp increase from 1961 to the mid-1980s, reaching a maximum in 1986. During the late 1980s and early 1990s energy supply declined by about $17 \%$. However, since 1993 it has risen again, going up by some $8 \%$ over the course of the last decade and a half.

Figures 2(b) and (c) show the trends in fat and protein supply between 1961 and 2007 according to the food balance sheet estimates and our calculated values. Once again, the trends are virtually identical. Our data revealed that fat supply has increased by approximately $32 \%$ over this period, while protein supply rose by $22 \%$. The food balance sheets do not report carbohydrate supply, but according to our calculations (data not shown) overall carbohydrate supply increased by 26\% between 1961 and 1980 but has fallen back by $15 \%$ since then.

\section{Contribution of macronutrients to total energy supply}

Figure 3 shows our calculated values for the contributions of protein, fat, carbohydrate and alcohol to total energy supply in Trinidad and Tobago between 1961 and 2007. In 1961 some $62 \%$ of energy was provided by carbohydrate, whereas by 1985 this figure had fallen to $56 \%$. Fats provided only $26 \%$ of energy in 1961 but by 1985 this figure had reached 31\%. Between 1986 and 1990 the figures began to diverge quite sharply, but since then the trend towards decreasing carbohydrate and increasing fat supply has become re-established, so that by 2007 the values were $57 \%$ of energy coming from carbohydrate and $30 \%$ of energy coming from fat. The contribution of protein to energy supply has remained relatively constant at about $12-14 \%$, while only about $1-2 \%$ of energy was contributed by alcohol.

\section{Sugars, starch and fibre}

Figure 4 shows the trends in sugars, starch and fibre (as NSP) supply in Trinidad and Tobago between 1961 and 2007. Sugars increased from $134 \mathrm{~g} /$ capita per $\mathrm{d}$ in 1961 to $199 \mathrm{~g} /$ capita per d in 2007, whereas starch supply fell from 274 to $235 \mathrm{~g} /$ capita per d. Between 1961 and 2007 the ratio of sugars to starch rose from $0 \cdot 49$ to $0 \cdot 89$. 


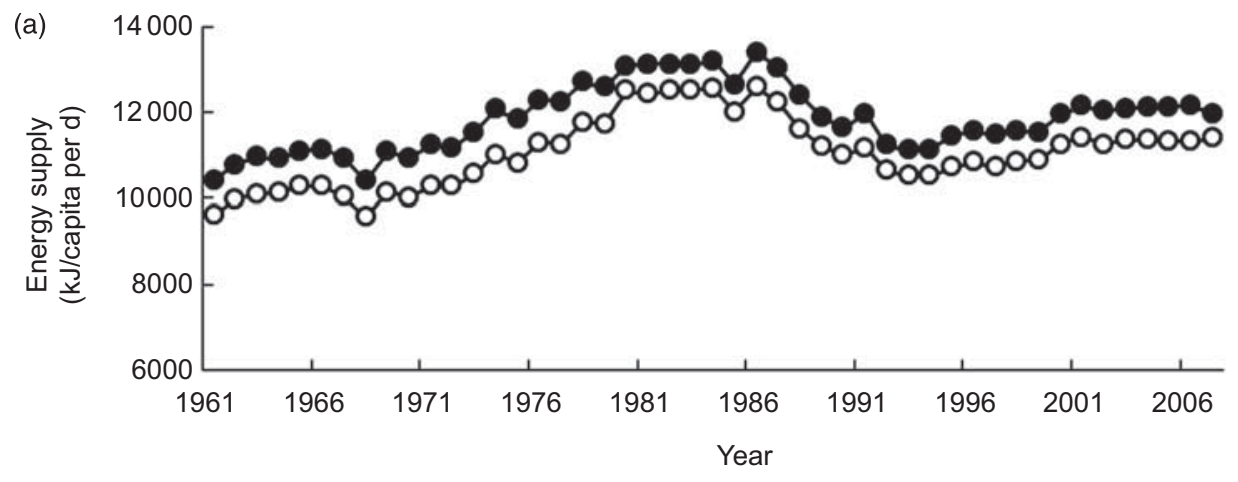

(b)

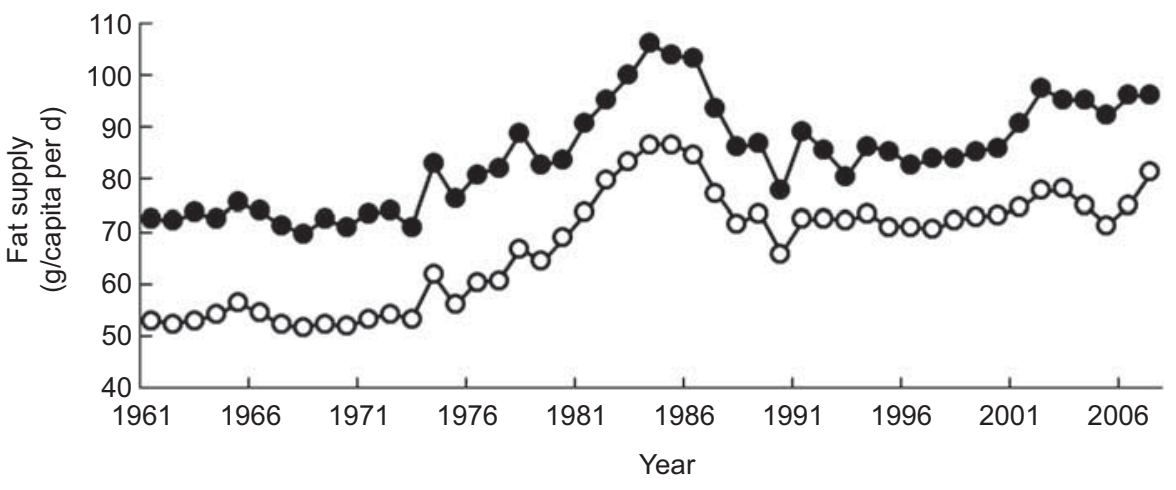

(c)

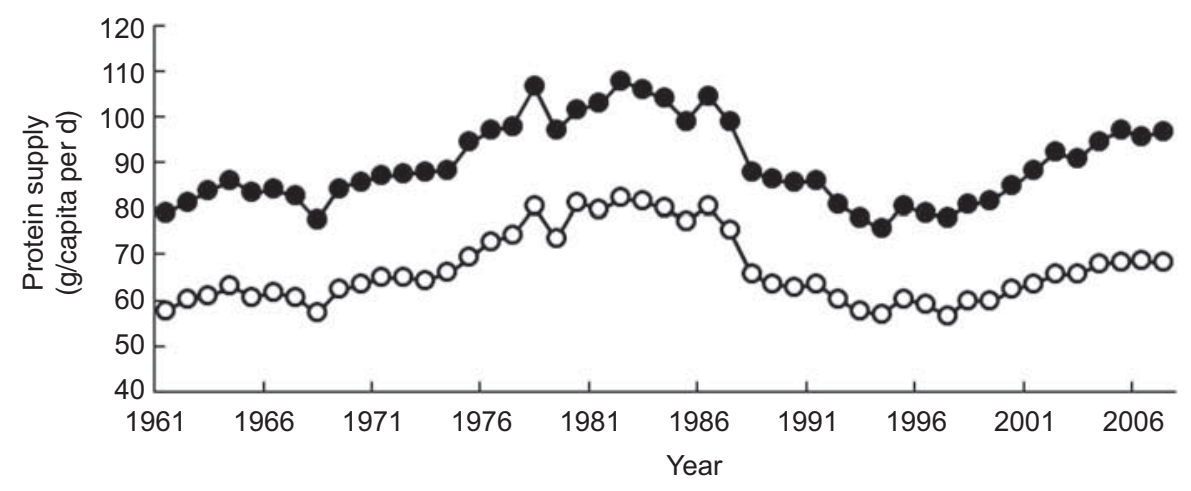

Fig. 2 Food balance sheet estimates $(\bigcirc)$ and our calculated values (o) for (a) energy (kJ/capita per d), (b) fat (g/capita per d) and (c) protein (g/capita per d) supply in Trinidad and Tobago between 1961 and 2007

Energy from sugars increased from $20 \%$ to $26 \%$ of total energy and most of this was in the form of non-milk extrinsic sugars (data not shown). The maximum value for NSP supply (36.2 g/capita per d) was recorded in 1986 and the minimum value $(25 \cdot 1 \mathrm{~g} /$ capita per $\mathrm{d})$ occurred in 1994. NSP supply in 2007 was $30 \cdot 3 \mathrm{~g}$ /capita per d.

\section{Saturated, monounsaturated and polyunsaturated fat and cholesterol}

Figure 5(a) shows the trends in saturated, monounsaturated and polyunsaturated fat supply in Trinidad and Tobago between 1961 and 2007. Between 1961 and the mid-1980s the most notable features were the consistently high level of saturated fats, at between $11 \%$ and $14 \%$ of energy, and the progressive rise in both monounsaturated and polyunsaturated fats. Between 1985 and 1990 the levels of saturated fat fell sharply from $13.2 \%$ to $9.9 \%$ of energy. By 2007 the contribution of saturated fats to total energy was about $10 \cdot 8 \%$, with monounsaturated and polyunsaturated fats contributing $8 \%$ and $6.5 \%$ of energy, respectively.

Figure 5(b) shows the change in the polyunsaturated: saturated (P:S) ratio of the food supply from 1961 to 2007. The P:S ratio more than tripled from 0.15 in 1961 to 0.50 in 1990 , reached a maximum of 0.73 in 2000 , and was 0.60 in 2007. Figure 5(b) also shows that the major factor associated with this shift in the P:S ratio, especially since the mid-1980s, was the increasing usage of soyabean oil. Soyabean oil supply rose from $0 \cdot 8 \mathrm{~g} /$ capita per d in 1961 to $17 \cdot 0 \mathrm{~g} /$ capita per d in 2007, whereas coconut oil, which it largely replaced, fell from $20 \cdot 6$ to $5 \cdot 8 \mathrm{~g} /$ capita per d over the same period (data not shown). Overall, the correlation between 


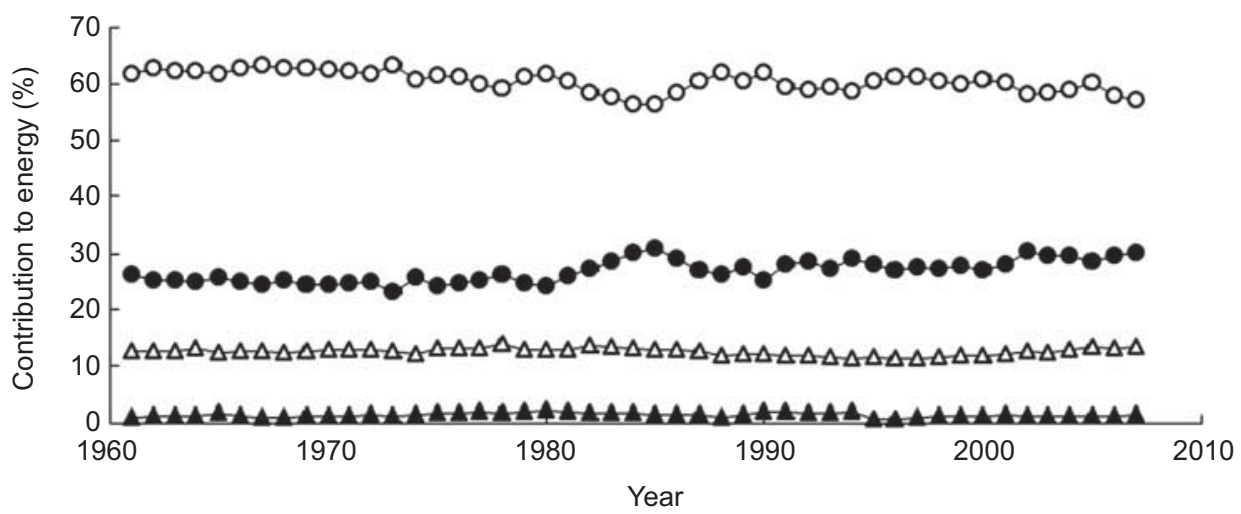

Fig. 3 Contributions of carbohydrate $(\bigcirc)$, fat $(\bullet)$, protein $(\triangle)$ and alcohol $(\boldsymbol{\Delta})$ to energy supply $(\%)$ in Trinidad and Tobago between 1961 and 2007

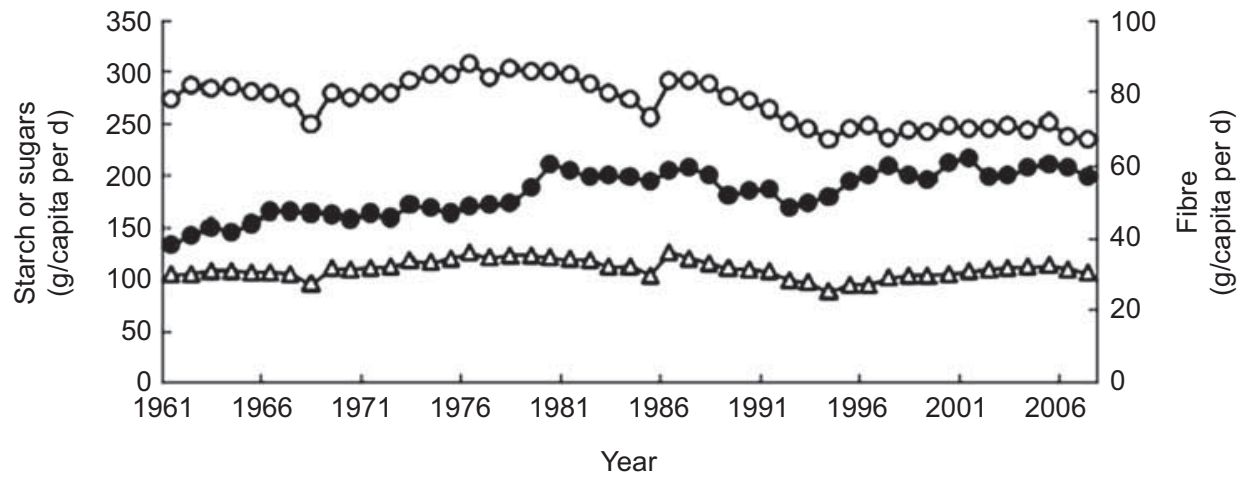

Fig. 4 Trends in starch (O), sugars (๑) and fibre (NSP; $\triangle$ ) supply (g/capita per d) in Trinidad and Tobago between 1961 and 2007
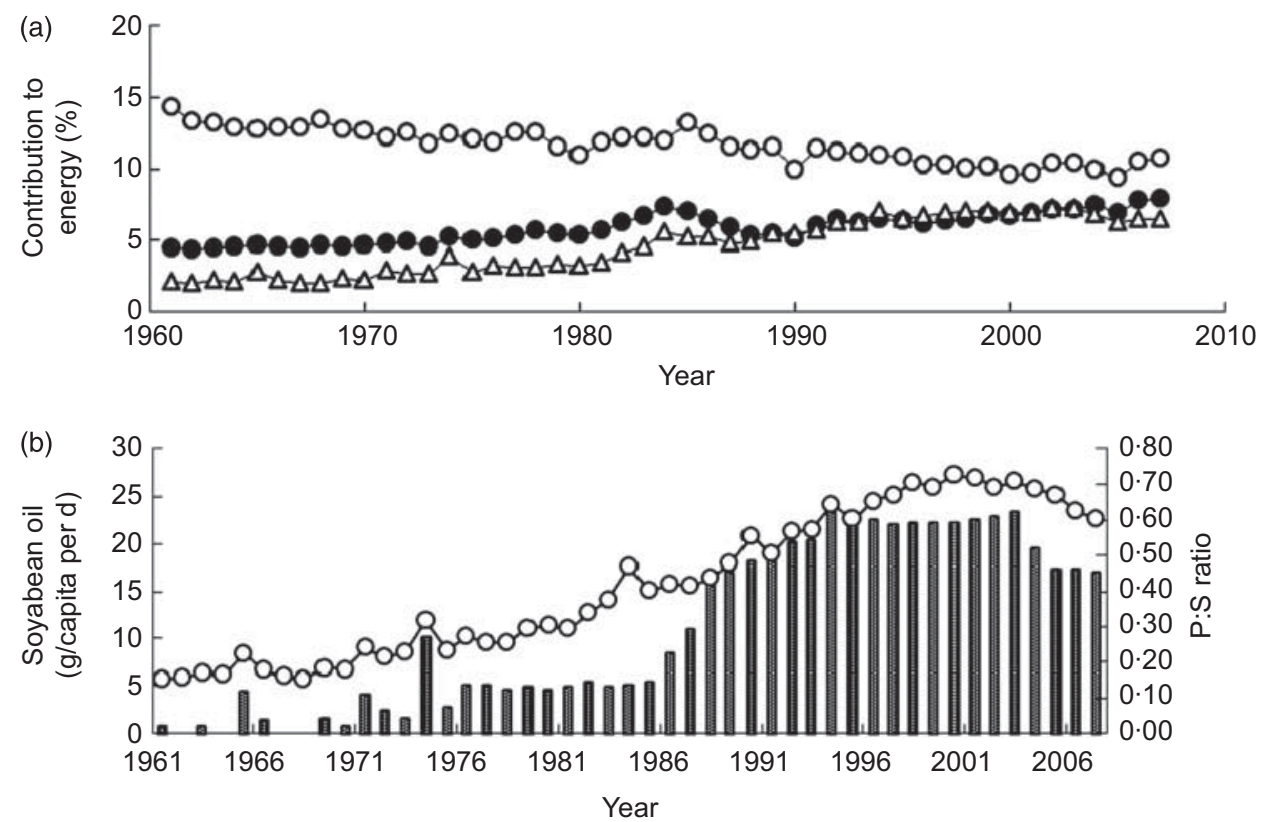

Fig. 5 (a) Contributions of SFA $(O)$, MUFA $(\bullet)$ and PUFA $(\triangle)$ to energy supply (\% of energy) and (b) relationship between polyunsaturated:saturated $(P: S)$ ratio of the food supply $(O)$ and supply of soyabean oil ( $\mathrm{g} /$ capita per d; 目) in Trinidad and Tobago between 1961 and 2007 


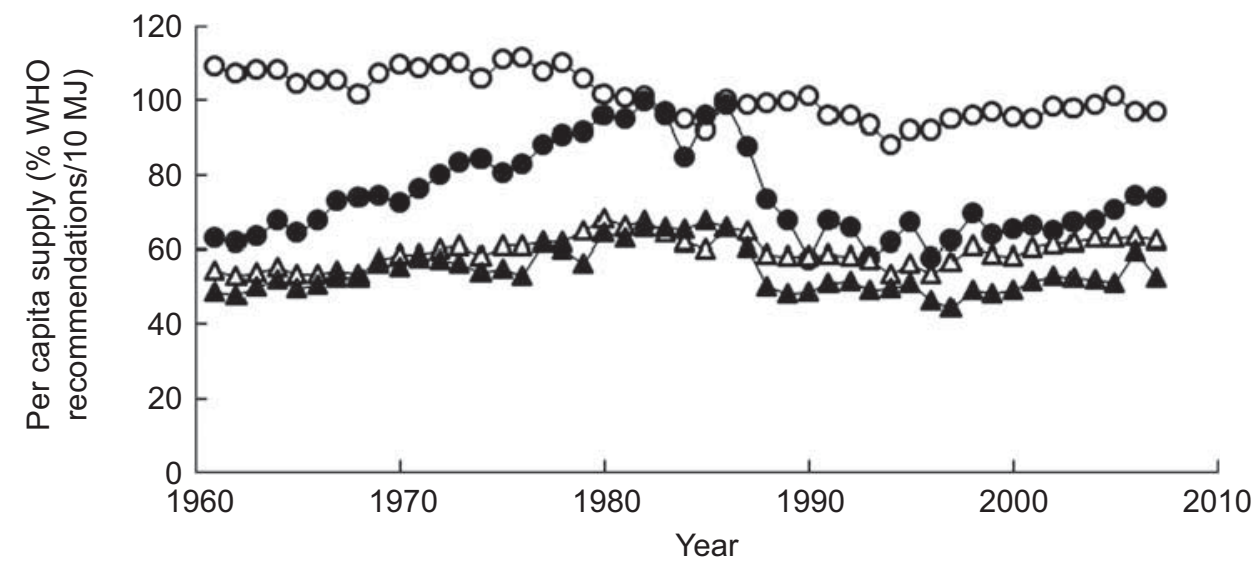

Fig. 6 Per capita supply of iron $(O)$, vitamin $A(\bullet)$, folate $(\triangle)$ and calcium $(\boldsymbol{\Delta})$ (expressed as percentage of WHO recommendations for adults aged 19-50 years per 10 MJ energy) in Trinidad and Tobago between 1961 and 2007

soyabean oil supply and the P:S ratio of the food supply was highly significant $\left(R^{2}=0.922, P<0 \cdot 0001\right)$.

Cholesterol supply increased from 124 to $225 \mathrm{mg} / \mathrm{capita}$ per d between 1961 and 2007 (data not shown), and was significantly correlated to milk $\left(R^{2}=0 \cdot 83, P<0 \cdot 0001\right)$ and meat $\left(R^{2}=0 \cdot 66, P<0 \cdot 0001\right)$ supply.

\section{Fe, vitamin A, Ca and folate}

Figure 6 shows the trends in Fe, vitamin A, Ca and folate supply in Trinidad and Tobago between 1961 and 2007. Values are expressed on a nutrient density basis as percentage of the mean WHO/FAO recommendations for males and females aged $19-50$ years per $10 \mathrm{MJ}(2390 \mathrm{kcal})$ energy $^{(19)}$. Fe supply exceeded the mean recommendation $(14 \cdot 4 \mathrm{mg} / \mathrm{d})$ between 1961 and the early 1980s but has been in a downward trend overall. Vitamin A supply rose from $63 \%$ to $99 \%$ of the mean recommendation $(550 \mu \mathrm{g}$ retinol equivalents/d) between 1961 and the early 1980s; however, during the last 20 years it has fallen back to less than $75 \%$ of the recommendation. For folate and $\mathrm{Ca}$, supplies ranged from approximately one-half to two-thirds of the mean recommendation of $400 \mu \mathrm{g}$ dietary folate equivalents/ $\mathrm{d}$ and $1000 \mathrm{mg} \mathrm{Ca} / \mathrm{d}$, respectively.

\section{Major food sources of protein, fat and carbobydrate}

Figure 7 shows the top three sources of (a) protein, (b) fat and (c) carbohydrate ( $\mathrm{g} /$ capita per $\mathrm{d}$ ) in Trinidad and Tobago between 1961 and 2007. Wheat is still the most important source of protein, providing more than $30 \mathrm{~g}$ protein/capita per $\mathrm{d}$, but its contribution has tended to fall over the last three decades. Poultry meat, on the other hand, is increasing in importance and is now the second highest source of protein, having overtaken milk. In the early 1960s, coconut oil was by far the most important source of fat. However since the early 1990s soyabean oil has taken over as the major fat source, followed closely by milk. For many years wheat was the most important source of carbohydrate but during the 1990s it was overtaken by sugar. Rice usage has been in long-term decline and rice now provides less than $30 \mathrm{~g}$ carbohydrate/ capita per d, compared with approximately $160 \mathrm{~g} /$ capita per d coming from wheat and sugar.

\section{Discussion}

The objective of the present study was to analyse the FAO food balance sheets for Trinidad and Tobago from 1961 to 2007 in order to characterise the changes that have taken place in the nutrient supply of the country during this period. The changes we observed, such as the increase in total energy supply, the growing contribution of fat and sugars to dietary energy, the dramatic increase in the P:S ratio due to the sudden shift to unsaturated oil usage in the 1980s, and the rapidly changing role of different commodities as nutrient sources, are characteristic features of the latest phase of the nutrition $\operatorname{transition}^{(20,21)}$.

Our calculated values for total energy, fat and protein supply were $7 \%, 25 \%$ and $35 \%$ higher, respectively, than those given on the food balance sheets. However both sets of values were significantly correlated (Figs 1(a) and (b)) and the trends observed over time were virtually identical, suggesting that coding of the commodities was appropriate. Absolute values can be expected to differ because there are differences between the food composition tables upon which our analysis was based ${ }^{(18)}$ and the older nutrient values used in the FAO statistical databases ${ }^{(22)}$. FAO cautions that for a variety of reasons these older compositional data may not be reflective, in many cases, of the foods and nutrients consumed today.

Our analysis showed that for Trinidad and Tobago, energy, protein and fat supply rose steadily from the early 1960s until the early to mid 1980s (Fig. 2), with energy supply reaching a maximum in 1986. The sharp falls that occurred between then and 1993 corresponded with 

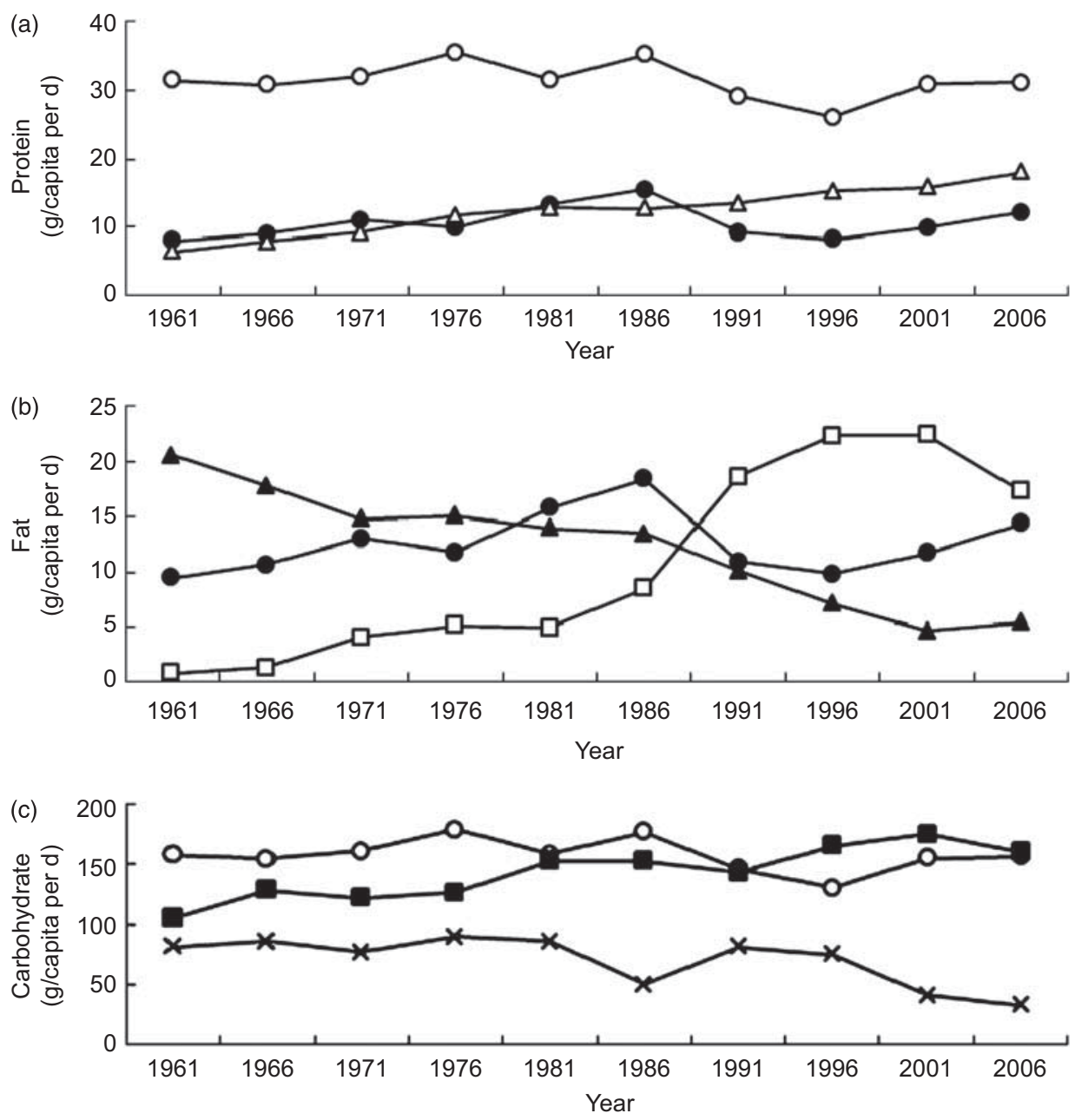

Fig. 7 Top three sources of (a) protein, (b) fat and (c) carbohydrate (g/capita per d) in Trinidad and Tobago between 1961 and 2007 (O, wheat; $\bullet$, milk; $\triangle$, poultry meat; $\boldsymbol{\Delta}$,coconut oil; $\square$, soyabean oil; $\boldsymbol{\square}$, sugar; $\times$, rice)

a period when the country was going through a deep recession brought about by a downturn in the price of oil, its major export commodity ${ }^{(23)}$. Our finding that the food supply in 2007 provided some $1561 \mathrm{~kJ}$ (373 kcal) more energy per capita daily than it did in 1961 is consistent with the observation of Kennedy ${ }^{(24)}$ that around the world as a whole there has been an average increase of approximately $2092 \mathrm{~kJ}$ (500 kcal)/capita per d in energy supply between 1961 and 1999.

The WHO recommends that 55-70\% of dietary energy should come from carbohydrate and 15-30\% should come from fat ${ }^{(12)}$. Our results (Fig. 3) show that during the early 1960s the food supply of Trinidad and Tobago had a high carbohydrate component (62-63\% of energy) while fat, at only $25-26 \%$ of energy, was well within the WHO recommendations. The most recent figures from 2007 , however, indicate that fat, at $30 \%$ of energy, is now at the upper limit of the WHO recommendations. Energy from carbohydrate is still within the recommended range; however a high and increasing proportion is in the form of sugars (Fig. 4). Sugars supply has been increasing at a rate of about $1 \%$ per annum, whereas starch supply - the main sources of which are wheat, rice, maize, potatoes and peas - has been falling at a rate of about $0.3 \%$ per annum. Consequently, in 2007, sugars provided about $26 \%$ of energy, with some $21 \%$ of energy being in the form of 'free' (or non-milk extrinsic) sugars (e.g. glucose, fructose, galactose, sucrose, maltose and oligosaccharides). The WHO recommendation is that $<10 \%$ of energy should be in the form of free sugars. Although the food balance sheets do account for the amounts of basic commodities (e.g. wheat, cocoa beans, milk, sugar, other sweeteners, etc.) used in the manufacture of products such as confectioneries and sweetened beverages, they provide no information on per capita consumption of these products. Thus the role these foods might be playing as potential sources of additional free sugars cannot be determined from the present analysis. For fibre, WHO recommends that intake should be $>25 \mathrm{~g}$ total dietary fibre/d or $>20 \mathrm{~g}$ $\mathrm{NSP} / \mathrm{d}$. Our data show that per capita supply of NSP was about $30 \mathrm{~g} / \mathrm{d}$ in 2007 . Although supply appears to be adequate, it is possible that intakes may not be because 
FAO food balance sheets make no allowances for losses that occur beyond the retail level ${ }^{(25)}$.

One of the most striking features seen in countries undergoing the nutrition transition is the effect that societal and economic changes (such as, for example, increasing wealth and urbanisation, and changes in food policies, agricultural practices, food processing, transportation and marketing) can have over relatively short periods of time on the relative usage of commodities that make up the bulk of the food supply in individual countries ${ }^{(26-28)}$. Wheat remains the single most important food commodity in Trinidad and Tobago and is a major source of both carbohydrate and protein (Fig. 7); however, sugar is now providing at least as much carbohydrate as wheat. On the other hand, rice, which during the 1960s was also an important source of carbohydrate, now provides less than one-fifth of the carbohydrate provided by either wheat or sugar. The increasingly important role being played by milk and especially poultry meat as protein sources signifies a shift towards animal product consumption that is also happening in other countries in nutritional transition $^{(28)}$. The sudden sharp increase in soyabean oil supply during the 1980s (Fig. 5) is especially interesting. Over a 9-year period between 1985 and 1994 soyabean oil supply quadrupled, and this, coupled with the continuous decline in coconut oil usage since the 1960s (Fig. 7), resulted in a dramatic increase in the P:S ratio of the food supply from 0.15 to 0.73 between 1968 and 2000 . Vegetable oil usage increased markedly through much of the world during the 1970s and 1980s, fuelled apparently by an aggressive publicity campaign by the vegetable oil industry against saturated fats because of their tendency to raise blood cholesterol, which led to the reformulation of products on a massive scale by food manufacturers ${ }^{(29,30)}$. The P:S ratio has been shown to be strongly and inversely related to CHD risk in adults ${ }^{(31)}$ and while there are no WHO recommendations for it, the UK Department of Health in 1984 recommended that it should be between $0 \cdot 23$ and $0 \cdot 45^{(32)}$.

For the majority of micronutrients, per capita supply (expressed per $10 \mathrm{MJ}$ of energy) met or exceeded WHO recommendations throughout the study period (data not shown). However, vitamin A, folate and Ca supplies were lower than recommended levels and Fe supply was borderline (Fig. 6). These observations need to be interpreted with caution because no allowance was made for either micronutrient bioavailability or fortification. Mandatory Fe fortification of flour does take place in Trinidad and Tobago ${ }^{(33-35)}$ and at least some flour is being fortified with folic $\operatorname{acid}^{(36)}$. Likewise, in the case of $\mathrm{Na}$, it is not possible to take into account $\mathrm{Na}$ or salt added during processing, cooking or at the table, since these events happen after the commodity stage. Thus further studies using different methodologies will be needed to ascertain the extent to which intakes of these micronutrients may be problematic.

\section{Limitations}

There are a number of limitations to the present study. As mentioned earlier, food balance sheets overestimate food consumption and nutrient intakes because they fail to take into account food waste or spoilage or other losses that occur after the retail level ${ }^{(25)}$. Also, they allow only for per capita estimates and lack the information necessary to analyse the population by sex, age and socio-economic status $^{(37)}$. Hence it is not possible to equate food balance sheet data directly with data generated using other techniques such as food consumption surveys because each approach measures different levels of dietary information $^{(38)}$. To try to overcome this limitation and facilitate at least some sort of comparison with official recommendations, we presented our data in relative terms (for example, as percentages of total energy, as ratios or per $10 \mathrm{MJ}$ of energy, as appropriate). Another limitation is that foods are listed on the food balance sheets as basic commodities rather than the specific products that individuals eat. This presents a challenge regarding how to code the data properly for nutritional analysis. For consistency, we coded at the level of the raw unprocessed commodity wherever possible; however, this could lead to an overestimation of some components - for example, fibre. Another important limitation is the lack of detail regarding the precise make-up of certain commodity groupings, such as types of fish, fruits and vegetables. To try to overcome this issue we populated these categories using information about commonly consumed foods from a QFFQ developed specifically for a Trinidadian population ${ }^{(17)}$. Although this could give only an approximation of true supply for these categories, it ensured that foods typically consumed in Trinidad and Tobago but which were not already specifically accounted for in the food balance sheets would be represented. The use of a UK rather than a Caribbean food composition database is another potential limitation, although basic commodities would not be expected to differ much in composition between the two countries. On the other hand, the UK database is extremely comprehensive, which facilitates more accurate coding.

\section{Conclusions}

Despite the inherent limitations of the food balance sheet approach, the present study revealed that changes in the food supply typical of the global nutritional transition have been taking place in Trinidad and Tobago since the early 1960s. These changes include an increase in overall energy supply and energy from fat, a fall in energy from carbohydrates, and a pronounced increase in both the sugars:starch ratio and the P:S ratio of dietary fats. Energy from fat is at the upper limit of WHO recommendations and energy from sugars is well above the recommended level. In addition, a number of important micronutrients including Ca, folate and vitamin A appear to be undersupplied. 
Further research should be carried out using different methodologies to try to confirm these findings. The imbalances in the Trinidadian food supply brought about by the nutrition transition need to be addressed in order to try to combat the rising tide of nutrition-related chronic diseases that are projected to cause increasing disability and premature death in the country over the coming years.

\section{Acknowledgements}

Sources of funding: This research received no specific grant from any funding agency in the public, commercial or notfor-profit sectors. Conflicts of interest: The authors declare they have no conflicts of interest. Ethics: Ethical approval was not required. Authors' contributions: T.S. conceived and designed the study, collated and analysed the data and drafted the manuscript. S.S. provided QFFQ data on commonly foods consumed in Trinidad and Tobago, critically reviewed the manuscript and revised it for important intellectual content. Acknowledgements: The authors express their sincere gratitude to FAOSTAT, Statistics Division of the $\mathrm{FAO}$, for allowing use of its data.

\section{References}

1. Foreign and Commonwealth Office (2011) Country profile: Trinidad and Tobago. http://www.fco.gov.uk/en/travel-andliving-abroad/travel-advice-by-country/country-profile/northcentral-america/trinidad-tobago (accessed October 2011).

2. WorldFacts.us (2011) Facts about Trinidad. http://worldfacts. us/Trinidad.htm (accessed October 2011).

3. Google Public Data Explorer (2011) World Bank, World Development Indicators. Life Expectancy: Trinidad and Tobago. http://www.google.com/publicdata/ explore?ds $=\mathrm{d} 5 \mathrm{~b}$ ncppjof8f9_\&met_y=sp_dyn_le00_in\&idim = country:TTO $\& \mathrm{dl}=\mathrm{en} \& \mathrm{hl}=\mathrm{en} \& \mathrm{q}=$ life + expectancy + trinidad $($ accessed October 2011).

4. Sinha DP (1995) Changing patterns of food, nutrition and health in the Caribbean. Nutr Res 15, 899-938.

5. Caribbean Commission on Health and Development, Pan American Health Organization \& Caribbean Community Secretariat Jamaica (2006) Report of the Caribbean Commission on Health and Development. http://www. who.int/macrohealth/action/PAHO_Report.pdf (accessed October 2011).

6. Ivey MA, Legall G, Boisson EV et al. (2008) Mortality trends and potential years of life lost in the English and Dutch-speaking Caribbean, 1985-2000. West Indian Med J 57, 122-131.

7. World Health Organization (2011) WHO Global Infobase. International Comparisons. https://apps.who.int/infobase/ Comparisons.aspx (accessed October 2011).

8. Boyne MS (2009) Diabetes in the Caribbean: trouble in paradise. Insulin 4, 94-105.

9. Miller GJ, Beckles GL, Maude GH et al. (1989) Ethnicity and other characteristics predictive of coronary heart disease in a developing community: principal results of the St. James Survey, Trinidad. Int J Epidemiol 18, 808-817.

10. Barceló A, Aedo C, Rajpathak R et al. (2003) The cost of diabetes in Latin America and the Caribbean. Bull World Health Organ 81, 19-27.

11. Ezenwaka CE \& Kalloo R (2003) Indices of obesity, dyslipidemia, and insulin resistance in apparently healthy Caribbean subjects. J Clin Lab Anal 17, 6-11.
12. World Health Organization (2003) Diet, Nutrition and the Prevention of Chronic Diseases. Joint WHO/FAO Expert Consultation. WHO Technical Report Series no. 916. Geneva: WHO.

13. Hiller JE \& McMichael AJ (1997) Ecological studies. In Design Concepts in Nutritional Epidemiology, 2nd ed., pp. 323-353 [B Margetts and M Nelson, editors]. Oxford: Oxford University Press.

14. FAOSTAT (2010) Food balance sheets. http://faostat.fao. org/site/368/default.aspx (accessed July 2010).

15. Sheehy T \& Sharma S (2010) The nutrition transition in Barbados: trends in macronutrient supply from 1961 to 2003. Br J Nutr 104, 1222-1229.

16. Sharma S, Cao X, Harris R et al. (2007) Dietary intake and development of a quantitative food-frequency questionnaire for the Barbados National Cancer Study. Public Health Nutr 10, 464-470.

17. Ramdath DD, Hilaire DG, Cheong KD et al. (2011) Dietary intake among adults in Trinidad and Tobago and development of a quantitative food frequency questionnaire to highlight nutritional needs for lifestyle interventions. Int $J$ Food Sci Nutr 62, 636-641.

18. Food Standards Agency (2002) McCance and Widdowson's The Composition of Foods, 6th ed. London: HMSO/OPSI.

19. World Health Organization \& Food and Agriculture Organization of the United Nations (2004) Vitamin and Mineral Requirements in Human Nutrition: Report of a Joint FAO/ WHO Expert Consultation, Bangkok, Thailand, 21-30 September 1998. http://whqlibdoc.who.int/publications/ 2004/9241546123_annexes.pdf (accessed October 2011).

20. Popkin BM (2001) The nutrition transition and obesity in the developing world. $J$ Nutr 131, issue 3, 871S-873S.

21. Popkin BM (1998) The nutrition transition and its health implications in lower-income countries. Public Health Nutr 1, 5-21.

22. Food and Agriculture Organization of the United Nations (2010) Food composition tables for international use. http://www.fao.org/docrep/x5557e/x5557e00.htm\#Contents (accessed October 2011).

23. Braumann B (1997) Unemployment Persistence and Capital Shortage: The Case of Trinidad and Tobago. IMF Working Paper no. WP/97/77. Washington, DC: International Monetary Fund, Western Hemisphere Department.

24. Kennedy G (2002) Global trends in dietary energy supply from 1961 to 1999. Food Nutr Agric (FAO) 30, 53-64.

25. Schmidhuber J \& Traill WB (2006) The changing structure of diets in the European Union in relation to healthy eating guidelines. Public Health Nutr 9, 584-595.

26. Du S, Mroz TA, Zhai F et al. (2004) Rapid income growth adversely affects diet quality in China - particularly for the poor! Soc Sci Med 59, 1505-1515.

27. Popkin BM, Duffey K \& Gordon-Larsen P (2005) Environmental influences on food choice, physical activity and energy balance. Physiol Behav 86, 603-613.

28. Popkin BM \& Du S (2003) Dynamics of the nutrition transition toward the animal foods sector in China and its implications: a worried perspective. J Nutr 133, 11 Suppl. 2, 3898S-3906S.

29. Fife B (editor) (2004) The truth about coconut oil. In The Coconut Oil Miracle, pp. 5-16. New York: Avery Publishing Company.

30. Fife BF 2006. Coconut oil and health. In Proceedings of the International Coconut Forum, 22-24 November 2005, Cairns, Australia. ACIAR Proc 125, 49-56.

31. Hu FB, Stampfer MJ, Manson JE et al. (1999) Dietary saturated fats and their food sources in relation to the risk of coronary heart disease in women. Am J Clin Nutr 70, 1001-1008.

32. Department of Health, Committee on Medical Aspects of Food Policy (1984) Diet and Cardiovascular Disease. Report on Health and Social Subjects no. 28. London: HMSO. 
33. Hurrell R, Ranum P, de Pee S et al. (2010) Revised recommendations for iron fortification of wheat flour and an evaluation of the expected impact of current national wheat flour fortification programs. Food Nutr Bull 31, 1 Suppl, S7-S21.

34. The Flour Fortification Initiative (2012) Country Profile Trinidad and Tobago. http://www.ffinetwork.org/country_ profiles/country.php? record=220 (accessed December 2012).

35. MOST/US Agency for International Development (2000) Summary of Mandatory and Voluntary Staple Food Fortification in Developing Countries. http://food-fortification.com/Files/ Download/Resources/MOST\%20\%20fortificationritu\%20.pdf (accessed December 2012).

\section{Appendix}

\section{Commodities listed in FAO food balance sheets}

Cereals - excluding beer: wheat; rice (milled equivalent); barley; maize; rye; cereals (other)

Starchy roots: cassava; potatoes; sweet potatoes; yams; roots (other)

Sugar crops: sugar (raw equivalent); sweeteners (other); honey

Pulses: beans; peas; pulses (other)

Treenuts

Oilcrops: soyabeans; groundnuts (shelled equivalent); sunflowerseed; rape and mustardseed; coconuts - including copra; sesameseed; olives

Vegetable oils: soyabean oil; groundnut oil; sunflowerseed oil; cottonseed oil; palmkernel oil; coconut oil; sesameseed oil; olive oil; maize germ oil
36. National Flour Mills Limited (2010) Bakers. http:// www.nfm.co.tt/Bakers/tabid/134/Default.aspx （accessed October 2011).

37. Jacobs K, Sumner DA 2002) The Food Balance Sheets of the Food and Agriculture Organization: A Review of Potential Ways to Broaden the Appropriate Uses of the Data. http://www.nfpcsp.org/agridrupal/sites/default/files/ FBS_Review_of_Potential_Ways_to_Broaden_the_Uses_of_ Data.pdf (accessed December 2012).

38. Serra-Majem L, MacLean D, Ribas L et al. (2003) Comparative analysis of nutrition data from national, household, and individual levels: results from a WHO-CINDI collaborative project in Canada, Finland, Poland, and Spain. J Epidemiol Community Health 57, 74-80.

Vegetables: tomatoes; vegetables (other)

Fruits - excluding wine: oranges; lemons; grapefruit; citrus (other); bananas; plantains; apples; pineapples; dates; grapes; fruits (other)

Stimulants: coffee; cocoa beans; tea

Spices: pepper; pimento; cloves; spices (other)

Alcoholic beverages: wine; beer; beverages (fermented); beverages (alcoholic)

Meat: bovine meat; mutton \& goat meat; pig meat; poultry meat; meat (other)

Animal fats: butter, ghee; cream; animal fats (raw); fish body oil; fish liver oil;

Milk - excluding butter

Eggs

Fish, seafood: freshwater fish: demersal fish; pelagic fish; marine fish; crustaceans; cephalopods; molluscs; other 